\title{
THE RELATIONSHIP OF THE BLOOD PYRUVIC ACID LEVEL TO DEFICIENCY STATES IN INFANCY AND CHILDHOOD
}

\author{
BY \\ E. C. ALlibONE, M.D., and E. FINCH, M.Sc. \\ (From the Children's Hospital, Birmingham)
}

Thiamin, acting in the form of its phosphoric ester co-carboxylase, is an enzyme necessary for the complete metabolism of glucose. In its absence glucose is broken down as far as pyruvic acid, which then accumulates until vitamin $\mathbf{B}_{\mathbf{1}}$ is supplied. Peters and Thompson (1934) and Peters (1936) demonstrated that the respiration of avitaminotic pigeon brain was reduced as compared with that of normal birds when either glucose, lactic or pyruvic acid was used as a substrate. The addition of crystalline vitamin $B_{1}$ raised the respiration to normal. It was shown that the vitamin acted on a three-carbon compound which was pyruvic acid. Thompson and Johnson (1935) found a raised pyruvic acid, measured as 'Bisulphite Binding Substance' (which includes all compounds with carbonyl groups), in the blood of avitaminotic animals. Shortly afterwards Platt and Lu (1936) reported its presence in the blood in cases of acute oriental beri-beri.

The establishment of a direct method by Peters and Thompson (1934) and Platt and Lu (1936) for the estimation of pyruvic acid has enabled this stage of carbohydrate metabolism to be extensively studied. Figures for the normal resting blood pyruvic acid in man have been determined by several investigators (Table 1), who all give mean values of less than $1.0 \mathrm{mg}$. per $100 \mathrm{c} . \mathrm{cm}$. of blood.

TABLE 1

NORMAL VALUES FOR PYRUVIC ACID IN BLOOD BY VARIOUS INVESTIGATORS

\begin{tabular}{|c|c|c|c|c|}
\hline Investigator & $\begin{array}{l}\text { Type of } \\
\text { case }\end{array}$ & Range & Mean & $\begin{array}{c}\text { Standard } \\
\text { devia- } \\
\text { tion }\end{array}$ \\
\hline $\begin{array}{l}\text { Lu (1939b) } \\
\text { Davis and } \\
\text { Bauer } \\
\text { (1944) } \\
\text { Friedemann } \\
\text { et al. (1945) } \\
\text { Golberg and } \\
\text { Gillman } \\
\text { (1943) } \\
\text { Wortis et al. } \\
\text { (1941) .. } \\
\text { Kato and Li } \\
\text { (1941) .. }\end{array}$ & $\begin{array}{l}\text { Adults } \\
\text { Adults } \\
\text { Adults } \\
\text { Men } \\
\text { Women } \\
\text { Adults } \\
\text { Children } \\
\text { Children }\end{array}$ & $\begin{array}{c}0.40-0.75 \\
0.50-1.30 \\
0.54-0.93 \\
- \\
- \\
0.77-1 \cdot 16 \\
0.71-1 \cdot 21 \\
0.60-1-00\end{array}$ & $\begin{array}{c}- \\
0.76 \\
0.79 \\
0.85 \\
0.98 \\
0.96 \\
0.80\end{array}$ & $\begin{array}{c}- \\
0-19 \\
0-19 \\
- \\
- \\
-\end{array}$ \\
\hline
\end{tabular}

The isolation of pyruvic acid from the blood of vitamin $B_{1}$ deficient animals was first reported by Johnson (1936). Platt and Lu (1939) found the blood pyruvic acid to be raised in acute beri-beri.

As pyruvic acid is a normal degradation product of glucose, the blood level represents the balance between its rate of formation in the tissues and the rate of destruction.

The level is increased in conditions of raised metabolism, after exercise (Johnson and Edwards, 1937; Lu and Platt, 1939), in thyrotoxicosis (Davis and Bauer, 1944), after glucose (Bueding et al., 1941) and in pyrexial states (Bueding et al., 1942). In all these conditions the giving of thiamin restored the levels promptly to normal. Davis and Bauer also found the level raised in liver disease but the administration of thiamin did not cause so great a fall as in controls.

Kato and Li (1941), working with children, found normal values for infective states as did Davis and Bauer (1944) in adults. Lu (1939b), however, observed in malnourished or infected rats that not only was the blood pyruvic acid raised, but the feeding of thiamin did not restore normality.

An alternative method for the assessment of the degree of vitamin $B_{1}$ saturation of the body is the determination of either the ordinary daily urinary excretion of thiamin or the urinary output following a test dose of the vitamin. The application of this method to children has been investigated and reviewed by Allibone and Finch (1945) who discussed the theoretical and practical limitations. It was because of its practical inapplicability as a routine test that the writers turned to the estimation of the blood pyruvic acid in the study of vitamin $\mathbf{B}_{1}$ nutrition in children and particularly in infants.

Method. In order to attain as near as possible a basic metabolism children over the age of a year were kept in bed on the morning of the estimation and the sample of blood taken fasting. Infants were not starved but the specimen was taken just before the midday feed. The patients had not recently received glucose intravenously which would give a high reading (Bueding and Goldfarb, 1943). The pyruvic acid was estimated by the NeubergCase method as subsequently modified by Peters and Thompson (1934), Lu (1939a), and Bueding and Wortis (1940).

After the initial estimation some infants were given $0.2 \mathrm{mg}$. thiamin after each feed, receiving 
1.0 to $1.2 \mathrm{mg}$. thiamin daily according to the number of feeds given. Other cases received, instead of thiamin, $3.0 \mathrm{~g}$. of yeast daily containing $0.27 \mathrm{mg}$. thiamin. The optimal requirements for infants of vitamin $B_{1}$ was found by Knott et al. (1943) to be $0.04 \mathrm{mg}$. per $\mathrm{kg}$. body weight. It was felt unwise to administer a larger quantity of yeast and although the amount of thiamin $(0.27 \mathrm{~g}$.) is only optimal for a weight up to $15 \mathrm{lb}$., it is probable that the other factors of the $B$ complex contained in the yeast assist in the metabolism of pyruvate, for Pilgrim et al. (1942) observed a decreased rate of pyruvate oxidation in liver from pantothenic and biotin deficient rats.

\section{Results}

INFANTS. Ninety-four babies under the age of one year were examined. They were nearly all admitted as acute cases with some form of infection, usually of the upper respiratory tract. Their ages ranged from a few days to a year, with an average of twenty weeks. In order to find the normal pyruvic acid level in the healthy infant under optimal conditions of nutrition, figures were taken from those cases which, before discharge from hospital, seemed to have made a complete clinical recovery in that they looked well, were afebrile, had a good appetite, normal stools and a consistent weight gain. Twenty babies gave a mean value of $0.78 \mathrm{mg}$. per $100 \mathrm{c} . \mathrm{cm}$. blood (Table 2). The figures are of

TABLE 2

PYRUVIC ACID IN BLOOD OF HEALTHY INFANTS

\begin{tabular}{c|c|c|c|c}
\hline $\begin{array}{c}\text { No. of } \\
\text { cases }\end{array}$ & Range & Mean & $\begin{array}{c}\text { Standard } \\
\text { error of } \\
\text { mean }\end{array}$ & $\begin{array}{c}\text { Standard } \\
\text { deviation }\end{array}$ \\
\hline 20 & $0-43-1-00$ & $\mathbf{0 - 7 8}$ & $\pm 0-05$ & 0.11 \\
\hline
\end{tabular}

the same order as for children and adults. As Bueding et al. (1941) considered any figure above $1.30 \mathrm{mg}$. to be abnormal, for purposes of analysis, a figure below 1.0 was considered to be optimal, from 1.0 to 1.30 borderline and above 1.30 definitely raised.

When all the infants were classified according to the above criteria, approximately a third had a normal pyruvic acid level in the blood, a further quarter were borderline and in the remaining 40 per cent. it was raised. Estimations made on fortynine babies within a week of discharge showed no significant change in these proportions (Table 3).

TABLE 3

GROLPING OF INFANTS ACCORDING TO THEIR BLOOD PYRUVIC ACID LEVEL, INITIALLY AND WHEN READY FOR DISCHARGE

\begin{tabular}{|c|c|c|c|c|c|}
\hline \multirow[b]{2}{*}{ Time } & \multicolumn{5}{|c|}{$\begin{array}{l}\text { No. of cases with pyruvic acid level } \\
\text { (in mg. per } 100 \text { c.c.) }\end{array}$} \\
\hline & $\mathrm{L}_{\mathrm{p}}$ to 1.00 & $1-01-1 \cdot 30$ & $1 \cdot 31-2 \cdot 0$ & Over $2-0$ & $\begin{array}{l}\text { Total } \\
\text { No. of } \\
\text { cases }\end{array}$ \\
\hline $\begin{array}{l}\text { Initial level } \\
\text { Prior to dis- }\end{array}$ & $\begin{array}{l}34 \text { (36 per } \\
\text { cent.) }\end{array}$ & $\begin{array}{c}23 \text { (24 per } \\
\text { cent.) }\end{array}$ & $\begin{array}{c}26(<7 \text { per } \\
\text { cent. })\end{array}$ & $\begin{array}{l}11(12 \text { per } \\
\text { cent.) }\end{array}$ & 94 \\
\hline charge .. & $\begin{array}{c}16(32 \text { per } \\
\text { cent.) }\end{array}$ & $\begin{array}{l}12(24 \text { per } \\
\text { cent.) }\end{array}$ & $\begin{array}{l}18 \text { ( } 36 \text { per } \\
\text { cent.) }\end{array}$ & $\begin{array}{l}3 \text { (6 per } \\
\text { cent.) }\end{array}$ & 49 \\
\hline
\end{tabular}

Serial blood levels were carried out on thirtythree infants who originally had a raised blood pyruvic acid. An average of four estimations per case was made at approximately weekly intervals. Most of the cases were of upper respiratory sepsis associated with parenteral diarrhoea. The duration of symptoms before receiving the vitamin ranged from seven to 150 days, with an average of forty days. There was no obvious relationship between the height of the pyruvic acid and the length of history. Levels of $2 \cdot 10,2 \cdot 00$ and $2 \cdot 70 \mathrm{mg}$. per 100 c.cm. blood resulted after illnesses of seven, eight and eight days respectively.

Table 4 shows the changes in the blood pyruvic

TABLE 4

CHANGE IN THE BLOOD PYRUVIC ACID IN 21 INFANTS FOLLOWING SUCCESSFUL TREATMENT OF AN INFECTION

\begin{tabular}{l|c|c|c|c}
\hline & \multicolumn{2}{|c|}{$\begin{array}{c}\text { Pyruvic acid } \\
\text { in mg. per 100 } \\
\text { c.c. }\end{array}$} & \multicolumn{2}{c}{$\begin{array}{c}\text { Duration of } \\
\text { treatment in } \\
\text { days }\end{array}$} \\
\cline { 2 - 5 } & Range & Mean & Range & Mean \\
\hline $\begin{array}{l}\text { Before treatment } . . \\
\text { After treatment } \ldots\end{array}$ & $\begin{array}{c}1 \cdot 20-2 \cdot 70 \\
0-43-1 \cdot 10\end{array}$ & $\begin{array}{c}1-89 \\
0-82\end{array}$ & $5-19$ & 12 \\
\hline
\end{tabular}

acid in twenty-one infants who responded promptly and fully to the treatment of the condition for which they were admitted. The cases are nearly the same as those listed in Table 2, though the criteria of good health were not so stringent. They were all suffering from an infection with the possible exception of two cases of marasmus and one each of congenital obliteration of the bile ducts and scurvy. Half of them received yeast and half thiamin as the vitamin supplement. The mean pyruvic acid level for the series fell from $1.89 \mathrm{mg}$. per $100 \mathrm{c} . \mathrm{cm}$. of blood to $0.82 \mathrm{mg}$. within an average period of twelve days.

In twelve of the thirty-three cases studied by repeated estimations, the pyruvic acid level continued to rise in spite of the vitamin supplements. In addition two cases, G.S. and A.M., which initially did well and were included in Table 4, relapsed clinically and biochemically and have been included in this series. In this group seven received thiamin and seven yeast.

Table 5 gives details of these cases. The mean of the initial pyruvic acid levels was $0.95 \mathrm{mg}$. per $100 \mathrm{c} . \mathrm{cm}$. blood, rising to $2.02 \mathrm{mg}$. and falling to $1.53 \mathrm{mg}$. before discharge. The duration of symptoms before vitamin therapy averaged forty-five days and the period over which vitamin supplements were given was twenty-nine days. The cause of the relapse with its associated signs are also shown, the commonest being diarrhoea and failure to gain weight.

CHILden. A number of children over the age of one year had isolated estimations done. No control cases are included. Their figures were all somewhat raised above normal values particularly in the presence of an infection (Table 6, Fig. 1).

The cases of coeliac disease were being treated with high doses of liver and vitamin B complex as recommended by May et al. (1942). Eighteen cases received a course of parenteral therapy consisting of daily alternating injections of $2 \mathrm{c.cm}$. of crude liver extract and $4 \mathrm{c.cm}$. of Beminal (vitamin B complex) for a period of three or, in some 


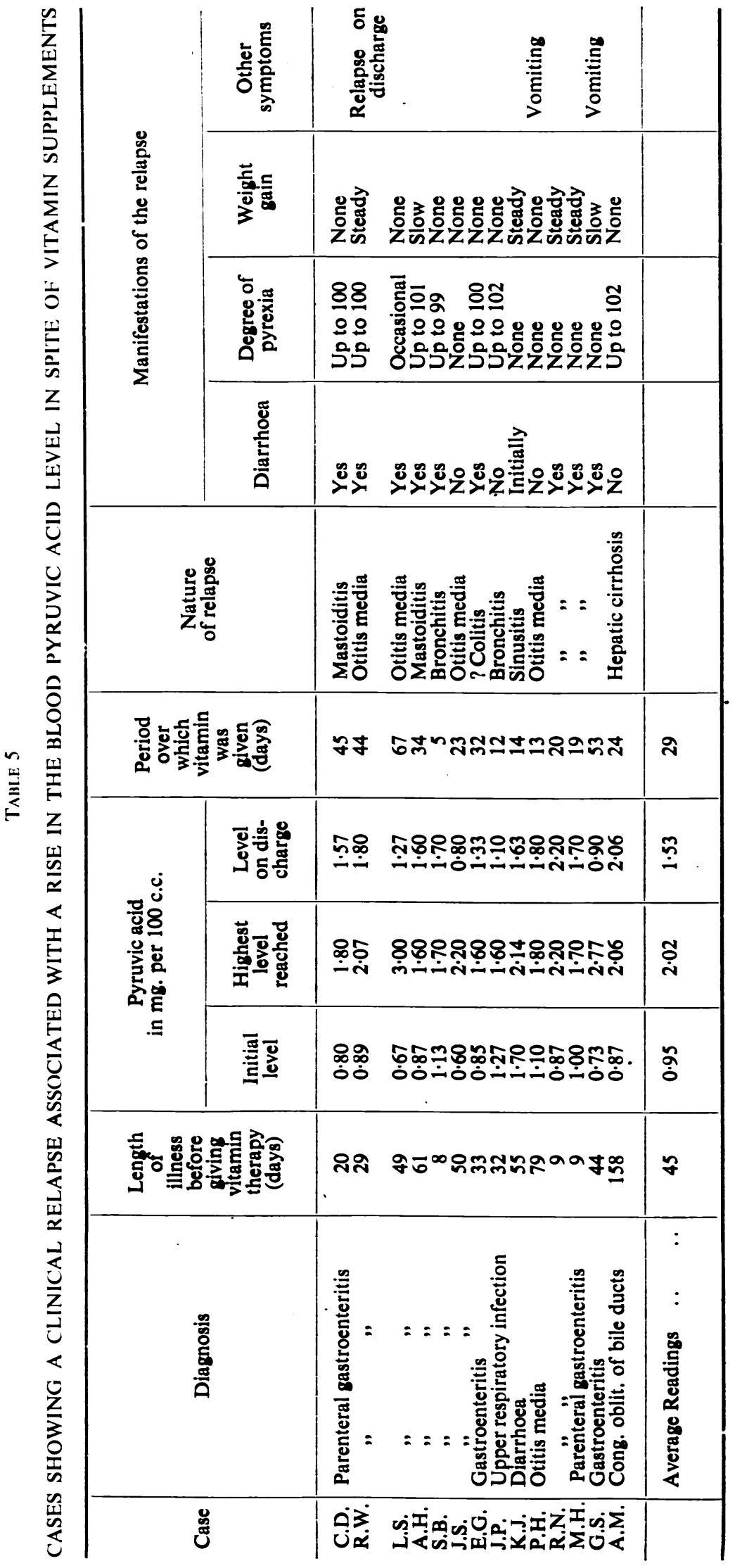


TABLE 6

BLOOD PYRUVIC ACID IN CHILDREN OVER THE AGE OF ONE YEAR, CLASSIFIED INTO GROUPS WITH AND WITHOUT AN ASSOCIATED SEPTIC PROCESS

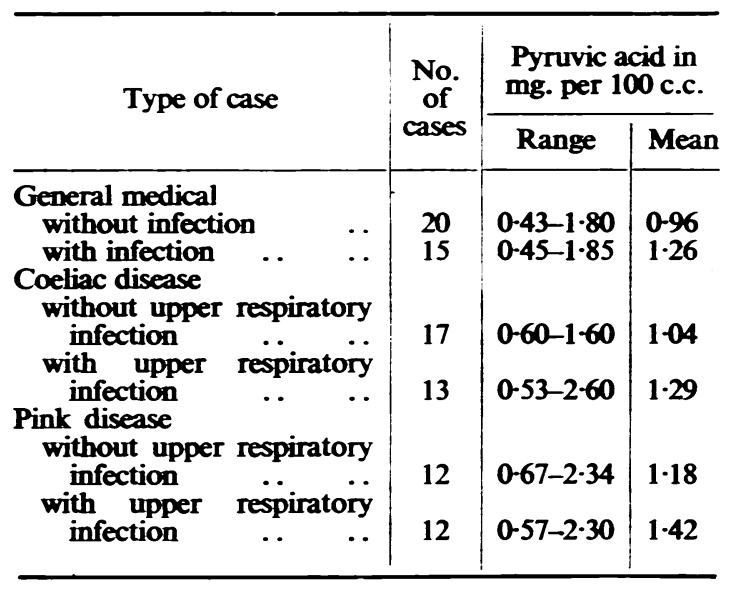

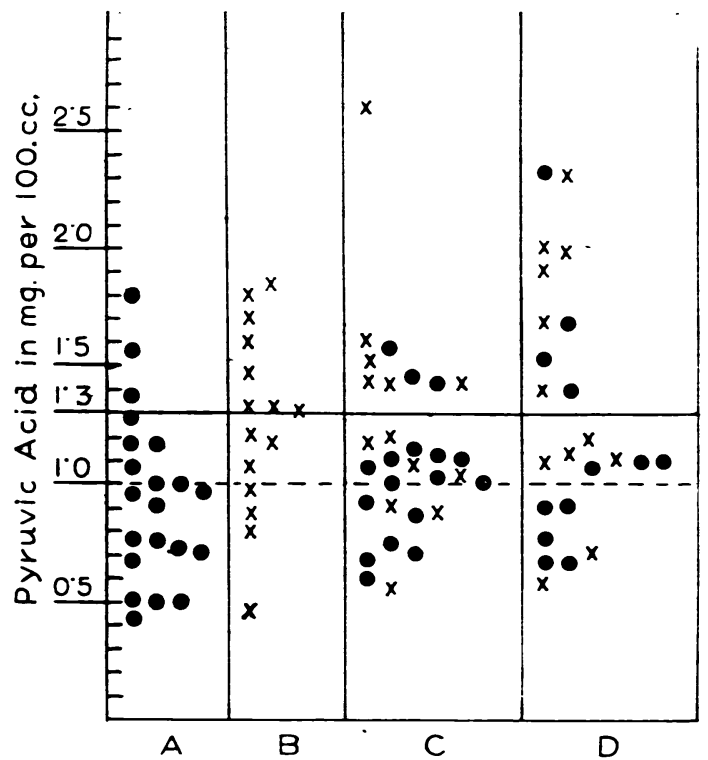

FIG. 1. Blood pyruvic acid levels in children over the age of one year.

- = Children without an infection.

$x=$ Children with an infection.

A Cases admitted for investigation.

B Cases admitted with an infection.

C Cases of coeliac disease.

D Cases of pink disease (all ages).

cases, six weeks. The children were then put on oral liver and oral vitamin B complex (Beminal) for six months when the estimations were repeated after allowing sufficient time for the immediate effects of the therapy to have worn off. No permanent change was observed either after the parenteral or the oral therapy (Table 7). Fig. 1 shows the distribution of the levels before treatment and the effect of the presence of an infection.

Twenty-four cases of pink disease were tested. Nine of these were under the age of a year and have already been included with the infants. As normal infants have the same pyruvic acid levels as
TABLE 7

BLOOD PYRUVIC ACID LEVELS IN COELIAC DISEASE, BEFORE AND AFTER TREATMENT WITH VITAMIN B COMPLEX

\begin{tabular}{ll|c|c|c|c}
\hline \multicolumn{1}{c|}{ Period } & & $\begin{array}{c}\text { No. } \\
\text { of } \\
\text { cases }\end{array}$ & \multicolumn{2}{|c|}{$\begin{array}{c}\text { Pyruvic acid in } \\
\text { mg. per 100 c.c. }\end{array}$} \\
\cline { 3 - 6 } & & Range & Mean \\
\hline $\begin{array}{llll}\text { Before treatment } \\
\text { After parenteral therapy }\end{array}$ & $\ldots$ & 18 & $0.69-2.60$ & 1.22 \\
After oral therapy & $\ldots$ & $\ldots$ & 9 & $0-63-2.93$ & 1.35 \\
\hline
\end{tabular}

older children, these nine cases have also been included in this series. Twelve cases without upper respiratory sepsis had a mean value for pyruvic acid of $1.18 \mathrm{mg}$. per $100 \mathrm{c.cm}$. In the presence of upper respiratory sepsis the mean was $1.42 \mathrm{mg}$. (Table 6, Fig. 1).

Four cases of post diphtheritic paralysis had values of $0.57,0.59,1.70$ and $2.10 \mathrm{mg}$.

In addition to the diseases already listed above, high pyruvic acid levels were obtained in single cases of acholuric jaundice (2.10 mg.), chronic beri-beri (1.97 mg.), and cirrhosis of the liver (2.61 mg.).

\section{Discussion}

A significant finding is the elevation of the blood pyruvic acid during a clinical relapse in spite of what would normally be an adequate intake of thiamin. In our series of fourteen cases showing this effect, the intercurrent infection produced diarrhoea in ten instances, cessation of weight gain in eight, with a slow gain in a further two. Six cases were frankly pyrexial. Although Bueding et al. (1942) found a raised figure in subjects with pyrexia, the latter does not appear to be an essential factor. The frequency of diarrhoea raises the question whether a failure of absorption from the gut plays a rôle. The diarrhoea was, however, in no case sufficiently severe to need parenteral therapy in order to maintain the fluid balance of the body. The feeds were weakened until the diarrhoea was controlled, and although the vitamin intake was thereby reduced, the supplement still gave a calculated optimal intake of thiamin. The only constant factor seems to have been a toxic or infective state. This deduction is supported by the findings in children over the age of a year (Table 6) who by and large did not suffer from diarrhoea, yet in whom the presence of an infection produced an elevation of the blood pyruvic acid. Lu (1939b) had found the same condition in experimental rats suffering from malnutrition or chronic infection.

The failure of many infants, when ready for discharge, to show a normal blood level is at first disconcerting. Owing to the demand for cots most infants were sent out as soon as it was felt that the mother could manage the baby. Of seven babies discharged with a blood pyruvic acid of $2.0 \mathrm{mg}$. or over, only one had begun to gain weight. It is common for this type of case to relapse on reaching home. In the past such an event has brought a latent 'Erewhonian' philosophy to the 
fore in the minds of the hospital staff and the unfortunate mothers have been viewed with severe disfavour for what was considered to be culpable mismanagement. It is evident that in these instances the baby, not having achieved metabolic equilibrium, will respond adversely to slight changes in routine and environment.

The ability of a toxic or infective state to produce an accumulation of pyruvic acid in the blood is further evidence that this elevation indicates faulty glucose metabolism without giving any lead as to the cause.

On the other hand, the level in beri-beri may not be raised. Platt and Lu $(1936,1939)$ found normal values in chronic beri-beri and even in some cases of the subacute form. Klein and Elsom (1944) produced experimentally subclinical thiamin deficiency in humans without causing any change in the pyruvic acid level, though the urinary thiamin excretion after a test dose was delayed.

In order to produce a more sensitive test, Lu and Platt (1939) utilized the property of exercise to precipitate an attack of acute cardiac beri-beri in a person with latent thiamin deficiency. In such individuals there was a marked rise in the blood pyruvic acid following exercise, although the resting level might be normal. Unfortunately this test, even if applicable to children, is not specific. Yanof (1943) obtained similar results in subjects with a poor physical condition, heart disease or hypertension.

While none of the infants showed any signs of beri-beri, the question arises whether the accumulation of pyruvic acid and possibly other B.B.S. in the blood is harmful and if so, can their removal be achieved by larger doses of vitamin?

Pyruvic acid injected intravenously into rabbits to a concentration of $10 \mathrm{mg}$. per $100 \mathrm{c.cm}$., is not toxic (Lu, 1939). There is, nevertheless, no doubt that a toxic factor operates in thiamin deficiency. The toxicity of breast milk in oriental beri-beri has been long known (Fehily, 1944). Geiger and Rosenberg (1933) showed that vitamin $B_{1}$ deficient dogs passed considerable quantities of methyl glyoxal in their urine. The phenomenon was observed in some of their toxic children. To what extent this occurs in infancy was beyond the scope of the present investigation.

No attempt has been made to determine the possibility of reducing a high blood pyruvic acid in a toxic infant by massive doses of thiamin. In a fatal case (Allibone and Baar, 1946) of a boy of three years with congestive heart failure due to a chronic beri-beri heart, with cirrhosis of the liver and a terminal pericarditis, $12.5 \mathrm{mg}$. of thiamin were given by intramuscular injection in divided doses daily. The blood pyruvic acid fell from $1.97 \mathrm{mg}$. to $1.13 \mathrm{mg}$. per $100 \mathrm{c.cm}$. in twenty-four hours, and three days later, on the day before death, was $0.70 \mathrm{mg}$. This boy had three conditions, congestive heart failure, hepati ccirrhosis and an infection, any one of which was capable of causing a raised blood pyruvic acid. That such an extreme case should respond to treatment suggests that most patients would react providing the dose were large enough. The necessity for a big dose of vitamin $\mathbf{B}_{1}$ is shown by the length of time required to lower the pyruvic acid in this case to normal. Platt and Lu (1939) found in adults with acute beri-beri that a single dose of 5-10 mg. thiamin lowered levels of 3.0 to $5.0 \mathrm{mg}$. to normal in about ten hours.

The cases of coeliac disease received massive doses. These children were loaded with the whole B complex. While on parenteral therapy they received $12 \mathrm{mg}$. thiamin every other day and when on oral therapy $19.8 \mathrm{mg}$. daily. The absence of a permanent response suggests a persistence of the metabolic dysfunction (Table 7).

A vitamin B deficiency has been thought to be a factor in the etiology of pink disease. For this reason these cases have been considered separately though, in the light of earlier conclusions, one would not expect the pyruvic acid level to be of much help in the elucidation of this point. As the presence of an upper respiratory infection was able to raise the mean pyruvic acid level from $1 \cdot 18 \mathrm{mg}$. to $1.42 \mathrm{mg}$. per $100 \mathrm{c} . \mathrm{cm}$. of blood, either the skin sepsis or the malnutrition would easily account for any elevation in those children without any upper respiratory trouble.

\section{Summary}

Normal resting levels for the pyruvic acid in the blood of infants ranged from 0.43 to $1.00 \mathrm{mg}$. per $100 \mathrm{c.cm}$., with a mean of $0.78 \mathrm{mg}$.

The presence of a toxic or infective state raised the blood pyruvic acid level in spite of an estimated adequate thiamin intake.

The elevation of the pyruvic acid is a valuable sign of a disturbance of carbohydrate metabolism, but gives no indication of the cause.

The implication of the above findings is discussed.

Thanks are due to Sir Leonard G. Parsons, Dr. E. M. Hickmans and Dr. H. S. Baar for their kind help and advice, and to the Honorary Staff of the hospital for permission to use their cases. One of us (E. F.) was in receipt of a grant from the Medical Research Council which has also defrayed the expenses of the laboratory work.

\section{REFERENCES}

Allibone, E. C. and Finch, E. (1945). Arch. Dis. Childh., 20, 169.

_, and Baar, H. S. (1946). Ibid., 21, 76.

Bueding, E., and Wortis, H. (1940). J. biol. Chem., 133,585 .

Stein, M. H., and Wortis, H. (1941). Ibid., 137, 793.

Wortis, H., and Stern, M. (1942). J. Clin. Invest., 21,85 .

, and Goldfarb, W. (1943). J. biol. Chem., 147, 33.

Davis, H. A., and Bauer, H. K. (1944). Arch. Surg., 48, 185.

Fehily, L. (1944). Brit. med. J., 2, 590.

Friedemann, T. E., Haugen, G. E., and Kmieciak, T. C. (1945). J. biol. Chem., 157, 673.

Geiger, A., and Rosenberg, A. (1933). Klin. Wschr., 12, 1258. 
Golberg, L., and Gillman, T. (1943). S. Afr. J. med. Sci., $8,117$.

Johnson, R. E. (1936). Biochem. J., 30, 31. , and Edwards, H. T. (1937). J. biol. Chem., 118, 427.

Kato, K., and Li, P. (1941). Amer. J. Dis. Child., 61, 1222.

Klein, D., and Elsom, K. O'S. (1944). Amer. J. med. Sci., 207, 247.

Knott, E. M., Kleiger, S. C., and Schlutz, F. W. (1943). J. Pediat., 22, 43.

Lu, G. D. (1939a). Biochem. J., 33, 249. (1939b). Ibid., 33, 774. , and Platt, B. S. (1939). Ibid., 33, 1538.
May, C. D., McCreary, J. F., and Blackfan, K. D. (1942). J. Pediat., 21, 289.

Peters, R. A. (1936). Lancet, 1, 1161.

- , and Thompson, R. H. S. (1934). Biochem. J., $28,916$.

Pilgrim, F. J., Axelrod, A. E., and Elvehjem, C. A. (1942). J. biol. Chem., 145, 237.

Platt, B. S., and Lu, G. D. (1936). Quart. J. Med., 5, 355.

, (1939). Biochem. J., 33, 1525.

Thompson, R. H.S., and Johnson, R. E. (1935). Biochem. J., 29, 694.

Wortis, H., Goodhart, R. S., and Bueding, E. (1941). Amer. J. Dis. Child., 61, 226.

Yanof, Z. A. (1943). Arch. intern. Med., 72, 239. 